Article

\title{
Revisiting Natural Resources-Globalization-Environmental Quality Nexus: Fresh Insights from South Asian Countries
}

\author{
Jian Xue ${ }^{1}$, Zeeshan Rasool ${ }^{1, *}$, , Raima Nazar ${ }^{2}$, Ahmad Imran Khan ${ }^{3}\left(\right.$, Shaukat Hussain Bhatti ${ }^{4}$ and Sajid Ali ${ }^{5}$ \\ 1 School of Economics and Management, Shaanxi University of Science and Technology, Xi'an 710021, China; \\ xuejian@sust.edu.cn \\ 2 Department of Economics, The Women University, Multan 60000, Pakistan; raima.6343@wum.edu.pk \\ 3 Putra Business School, University of Putra, Seri Kembangan 43400, Malaysia; \\ ahmadimran.phd_fin18@grad.putrabs.edu.my \\ 4 Department of Law, Times Institute, Multan 60000, Pakistan; shaukathussain78682@gmail.com \\ 5 School of Economics, Bahauddin Zakariya University, Multan 60000, Pakistan; sajidali1136@gmail.com \\ * Correspondence: zeeshan_rasool114@hotmail.com
}

Citation: Xue, J.; Rasool, Z.; Nazar, R.; Khan, A.I.; Bhatti, S.H.; Ali, S. Revisiting Natural ResourcesGlobalization-Environmental Quality Nexus: Fresh Insights from South Asian Countries. Sustainability 2021, 13, 4224. https://doi.org/ $10.3390 /$ su13084224

Academic Editor: Pallav Purohit

Received: 1 March 2021

Accepted: 5 April 2021

Published: 10 April 2021

Publisher's Note: MDPI stays neutral with regard to jurisdictional claims in published maps and institutional affiliations.

Copyright: (c) 2021 by the authors. Licensee MDPI, Basel, Switzerland. This article is an open access article distributed under the terms and conditions of the Creative Commons Attribution (CC BY) license (https:// creativecommons.org/licenses/by/ $4.0 /)$.

\begin{abstract}
Widespread interference of human activities has resulted in major environmental problems, including pollution, global warming, land degradation, and biodiversity loss, directly affecting the sustainability and quality of the environment and ecosystem. The study aims to address the impact of the extraction of natural resources and globalization on the environmental quality in the South Asian countries for the period 1991-2018. A new methodology Dynamic Common Correlated Effects is used to deal with cross-sectional dependence. Most previous studies use only carbon dioxide emissions, which is an inadequate measure of environmental quality. Besides carbon dioxide emissions, we have used other greenhouse gas emissions like nitrous oxide and methane emissions with a new indicator, "ecological footprint". Long-run estimation results indicate a positive and significant relationship of natural resources with all greenhouse gas emissions and a negative association with the ecological footprint. Globalization shows a negative association with carbon dioxide emissions and nitrous oxide emissions and a positive relationship with the ecological footprint. Institutional performance is negatively correlated with carbon dioxide emissions, methane emissions, and ecological footprint while positively associated with nitrous oxide emissions. The overall findings highlight the pertinence of reducing greenhouse gas emissions and ecological footprint, proper utilizing of natural resources, enhancing globalization, and improving institutional performance to ensure environmental sustainability.
\end{abstract}

Keywords: globalization; natural resources; greenhouse gas (GHG) emissions; ecological footprint; cross-sectional dependence (CSD); dynamic common correlated effects (DCCE) estimation

JEL Classification: F64; N55; F64; E02

\section{Introduction}

Natural resources have a significant role for the countries, especially for underdeveloped economies that depend on extracting these resources for a substantial part of their national income [1,2]. Natural resources help improve environmental quality and play a significant role in enhancing economic growth [2]. On the other hand, human activities deteriorate the environment and reduce land's production capacity [3,4]. Natural resources like fishing grounds, croplands, forests, and grazing lands give capital for energy production by offsetting the human-caused emissions [5]. Furthermore, the extraction of some natural resources, such as petroleum, gas, and coal, deteriorates the environmental quality $[3,6]$.

Due to globalization, the countries of the world are economically, politically, and socially interlinked with each other. These economic, political, and social aspects affect 
the environmental quality [7-9]. Globalization is explained as the shifting of isolated and self-constrained countries with investment and trade barriers and/or cultural diversities to more interdependent and integrated economies [7]. Grossman and Krueger [10] define the mechanisms of scale, composition, and technique effect by which globalization can affect the environment. The scale effect represents the expansion of economic activities through which the use of natural resources and energy deteriorates the environmental quality in the economy. The composition effect refers to structural changes, i.e., an economy that moves its production towards capital-intensive technology (dirty goods) will generate more pollution than the economy that shifts its output towards labor-intensive technology (clean products) $[10,11]$. According to the technique effect of globalization, the environmental quality improves in host economies due to the transfer of better and new technologies [12-14]. Another significant but somewhat neglected measure that also influences environmental quality is institutional performance $[15,16]$. It is suggested that specific institutional conditions like corruption, the rule of law, bureaucratic quality, and risk of expropriation affect environmental quality, and pollution can be reduced by strengthening these institutions through enforcement of environmental regulations [17-19]. It implies a sophisticated structure going through various institutional means and impacts both market and political forces [19].

Many researchers have used greenhouse gas (GHG) emissions as environmental quality measures, such as sulfur dioxide $\left(\mathrm{SO}_{2}\right)$, carbon dioxide $\left(\mathrm{CO}_{2}\right)$, methane $\left(\mathrm{CH}_{4}\right)$, nitrous oxide $\left(\mathrm{N}_{2} \mathrm{O}\right)$, and sulfur hexafluoride $[20,21]$. Another new indicator, which is known as the "ecological footprint", is also used in some new studies as a measuring method for the sustainable ecological system $[17,22,23]$. The ecological footprint can be considered as a significant indicator of environmental quality in biologically productive areas. It is a logical device for considering the depletion of resources. It compares the regenerative or constructive capacity of the ecological system of earth and highlights the impacts of consumption and production on the environmental quality $[2,24]$.

\section{A Snapshot of Environmental Situation in South Asia}

South Asia is the world's most heavily populated region, having just $3.4 \%$ of world land but providing shelter for nearly one-fourth of the global population. The region is confronted with environmental challenges, rendering life insufferable for over 1.8 billion people. The prevailing situation is further exacerbated by population explosion, rapid urbanization and industrialization, and is considered a disaster zone of climate change [25]. South Asia is facing the consequences of environmental degradation like erratic monsoon rains, water shortage, low agricultural products, and rising temperature. Climate change also affects the ecosystems, which results in unfavorable effects on livestock, farming, forests, grazing land, and fishing [25]. The adverse effects of climate change have risen over the past two decades in South Asia. In 2007, Pakistan was affected by an unprecedented flood. In 2017, millions of people were displaced and killed due to unexpected monsoon season in Bangladesh, India, and Nepal. It is expected that rising sea levels will dislocate 18 million people in Bangladesh and Maldives over the next 40 years [26]. South Asian region consumes only $6 \%$ of the world's energy. Among South Asian countries, India has the largest crude oil reserves. Sri Lanka and Pakistan hold 150 and 324 million barrels of crude oil, respectively [27]. If India and Pakistan continue to consume oil at the present rate, they will run out of reserves in the next three to four decades. India, Pakistan, and Afghanistan hold natural gas reserves of 39, 33, and 15 trillion cubic meters, respectively [28].

The tremendous growth of energy consumption in South Asia has been followed by various environmental consequences. India generates approximately $75 \%$ of total regional $\mathrm{CO}_{2}$ emissions, though per capita $\mathrm{CO}_{2}$ emissions remain low. Since 1990, the level of GHG emissions and ecological footprint in South Asia has been increasing. In 2018, the average annual per capita $\mathrm{CO}_{2}$ emissions was estimated at 1.92, 1.90, 1.23, 0.99, 0.58, and 0.35 metric tons in India, Bhutan, Sri Lanka, Pakistan, Bangladesh, and Nepal, respectively (see Table 1). On the other hand, in the year 2018, the per capita ecological footprint was1.21, 0.87, 1.09, 
0.85, 1.60, and 4.53 global hectares in India, Pakistan, Nepal, Bangladesh, Sri Lanka, and Bhutan, respectively (see Table 1).

Table 1. Trends of Greenhouse Gas (GHG) Emissions and Ecological Footprint in South Asian Countries.

\begin{tabular}{|c|c|c|c|c|c|c|}
\hline & India & Pakistan & Nepal & Bangladesh & Sri Lanka & Bhutan \\
\hline Year & \multicolumn{6}{|c|}{$\mathrm{CO}_{2}$ Emissions (Metric Tons Per Capita) } \\
\hline 1990 & 0.71 & 0.64 & 0.04 & 0.14 & 0.22 & 0.24 \\
\hline 2000 & 0.98 & 0.75 & 0.13 & 0.22 & 0.55 & 0.67 \\
\hline 2010 & 1.39 & 0.94 & 0.19 & 0.41 & 0.65 & 0.71 \\
\hline 2012 & 1.59 & 0.90 & 0.23 & 0.44 & 0.79 & 1.19 \\
\hline 2015 & 1.78 & 0.94 & 0.33 & 0.52 & 0.96 & 1.46 \\
\hline 2018 & 1.92 & 0.99 & 0.35 & 0.58 & 1.23 & 1.90 \\
\hline Year & \multicolumn{6}{|c|}{$\mathrm{N}_{2} \mathrm{O}$ Emissions (Thousand Metric Tons of $\mathrm{CO}_{2}$ Equivalent) } \\
\hline 1990 & $169,598.5$ & $18,443.5$ & 3591.3 & $16,201.4$ & 1759.4 & 178.7 \\
\hline 2000 & 207,700 & 26,350 & 4231.7 & 20,770 & 2044.5 & 281.1 \\
\hline 2010 & $234,135.9$ & $30,050.2$ & 4508.1 & $26,159.6$ & 2131.6 & 544.1 \\
\hline 2012 & $239,755.1$ & $30,651.2$ & 4518.2 & $26,682.8$ & 2174.2 & 555.1 \\
\hline 2015 & $256,226.4$ & $32,231.1$ & 4532.8 & $30,574.7$ & 2197.2 & 847.1 \\
\hline 2018 & $271,058.5$ & 33,680 & 4545.6 & $33,800.9$ & 2241.3 & 1088.5 \\
\hline Year & \multicolumn{6}{|c|}{$\mathrm{CH}_{4}$ Emissions (kt of $\mathrm{CO}_{2}$ Equivalent) } \\
\hline 1990 & 513,704 & $90,807.8$ & $20,285.7$ & $87,092.7$ & $11,514.1$ & 918.9 \\
\hline 2000 & 561,733 & 117,125 & $21,206.1$ & $89,247.2$ & 9606.1 & 1032.4 \\
\hline 2010 & 621,480 & 155,232 & 23,512 & 103,080 & $11,630.9$ & 1734.9 \\
\hline 2012 & $636,395.8$ & $158,336.6$ & $23,982.2$ & $105,141.6$ & $11,863.52$ & 1769.6 \\
\hline 2015 & $659,538.5$ & $165,716.9$ & $24,732.7$ & $111,341.8$ & $12,389.14$ & 2318.9 \\
\hline 2018 & $681,817.2$ & $172,265.2$ & $25,443.6$ & $116,950.8$ & $12,912.47$ & 2771.3 \\
\hline Year & \multicolumn{6}{|c|}{ Ecological Footprint (Per Capita Global Hectares) } \\
\hline 1990 & 0.76 & 0.73 & 0.80 & 0.47 & 0.83 & 4.04 \\
\hline 2000 & 0.83 & 0.81 & 0.84 & 0.54 & 1.18 & 4.38 \\
\hline 2010 & 1.05 & 0.83 & 0.92 & 0.72 & 1.30 & 4.16 \\
\hline 2012 & 1.09 & 0.78 & 0.95 & 0.73 & 1.38 & 4.56 \\
\hline 2015 & 1.13 & 0.80 & 0.96 & 0.79 & 1.54 & 4.47 \\
\hline 2018 & 1.21 & 0.87 & 1.09 & 0.85 & 1.60 & 4.53 \\
\hline
\end{tabular}

Source: World Bank, World Development Indicators database, Global Footprint Network.

Although many studies have analyzed the environmental issues for various groups of countries, for South Asian countries, activities in this important field are severely limited, and the integrated research in this subject is even missing [29]. Hence, this research contributes to the existing literature by filling the existing gap in the following ways: (i) though the association between natural resources, globalization, and environmental quality has been examined by some scholars, the relationship has not yet been clear [29], which calls for further investigation. No study is available currently that has evaluated the impact of the extraction of natural resources and globalization on environmental quality in South Asian countries. (ii) Unlike previous research, the current study applies a novel methodology, Dynamic Common Correlated Effects (DCCE), which can consider various methodological problems such as cross-sectional dependence (CSD) and heteroscedasticity(iii)As an environmental measure, the majority of current literature only uses $\mathrm{CO}_{2}$ emissions. It can be misleading to use a single proxy to capture environmental effects [30]. This study, therefore, deals with environmental problems in a modern sense by using four proxies of environmental quality (GHG emissions, i.e., $\mathrm{CO}_{2}, \mathrm{~N}_{2} \mathrm{O}$, and $\mathrm{CH}_{4}$ together with a novel indicator, ecological footprint) to obtain robust findings.(iv)Instead of using a single indicator of institutional performance, this study uses a composite index made up of five different institutional indicators (socioeconomic condition, government stability, corruption, investment profile, and law and order) through principal component analysis (PCA) technique.(v)Environmental issues in South Asian countries have a great interest for 
governments, policymakers, and researchers due to its rising levels of GHG emissions and ecological footprint. (vi) Thus, this research gives useful proposals, which will open new doors for further research in environmental issues and its implications.

The rest of the paper is structured as follows: the empirical review of the previous literature is provided in Section 3. Data and methodology are given in Section 4, while Section 5 provides results and discussion. In the end, Section 6 concludes the study with some policy recommendations.

\section{Literature Review}

This section evaluates the impact of the extraction of natural resources and globalization on environmental quality by providing a brief review of the previous literature.

Since the early studies of Young [31], Sachs and Warner [32], and Auty [33], extensive consideration has been given to the extraction of natural resources and environmental quality worldwide. Recently, many studies emphasize the importance of natural resources for sustainable development and environmental quality. For instance, Neumayer [34] explained the impact of natural resources on environmental quality by using $\mathrm{CO}_{2}$ emissions and confirmed that natural resources significantly explained the cross-country differences in $\mathrm{CO}_{2}$ emissions. Gao and Tian [1] analyzed the ecological trade deficit and excess consumption of natural resources for China. It was indicated that, in 1986, due to excess consumption of resources, the production footprint of China surpassed its biocapacity, which was called ecological overshoot. Hassan et al. [2] observed that natural resources increased the amount of ecological footprint, while Zafar et al. [21] argued that natural resources mitigated the ecological footprint. Similarly, Bai et al. [4] found that natural factors had a positive relationship with air pollution. The risk detector analysis revealed that precipitation and elevation had a negative impact on air pollution, whereas urbanization was positively correlated with air pollution. In another study, Balsalobre-Lorente et al. [3] analyzed the impact of natural resources, electricity consumption and economic growth on $\mathrm{CO}_{2}$ emissions for European Union countries for the years 1985-2016. The findings confirmed that both natural resources and electricity consumption improved the environment.

The globalization-environmental quality nexus has drawn much attention in recent years. Dreher et al. [35] analyzed the association between globalization and various environmental indicators, such as $\mathrm{SO}_{2}$ emissions and $\mathrm{CO}_{2}$ emissions, water pollution, and round wood production. After applying panel regression models, it was revealed that globalization migrated $\mathrm{SO}_{2}$ emissions and water pollution. However, globalization did not influence $\mathrm{CO}_{2}$ emissions and round wood production. Twerefou et al. [36] evaluated the link between globalization and carbon dioxide emissions for 36 African countries. By using the GMM method, it was disclosed that globalization degraded environmental quality in selected African countries. In another study, Mrabet and Alsamara [30] explored the validity of the Environmental Kuznets Curve (EKC) in Qatar by using ecological footprint and $\mathrm{CO}_{2}$ emissions. After applying the ARDL model, it was found that EKC is not valid in Qatar by using $\mathrm{CO}_{2}$ emissions, whereas EKC was found by using ecological footprint. In a recent study, Sharif et al. [37] suggested that globalization and ecological footprint had a positive impact on each other in the case of Sweden, Belgium, the Netherland, Denmark, Norway, Switzerland, Portugal, and Canada. On the other hand, in Germany, France, and Hungary, a negative relationship was observed between globalization and ecological footprint.

The previous studies linked many institutional performance indicators to environmental quality. As pioneer studies, Deacon [38] and Torras and Boyce [39] found that good governance and democracy improved environmental quality. The positive association between institutional performance and environmental quality is verified by many scholars. For instance, Deacon [38] and Dasgupta et al. [18] identified a positive association between institutional quality and environmental quality. Cole [40], in his empirical study of 94 countries, realized that corruption had a positive association with $\mathrm{SO}_{2}$ and $\mathrm{CO}_{2}$ emissions. Similarly, a positive association between the control of corruption and $\mathrm{SO}_{2}$ 
emissions was also examined by Liao et al. [16] in 29 Chinese provinces. It was observed that institutional performance improved environmental quality even if an economy had a low level of income.Zeinalzadeh et al. [41] found a positive association between democracy and environmental quality in OIC countries for the period 2000-2010. Charfeddine and Mrabet [42] analyzed the energy consumption-environmental quality nexus via social and political factors in MENA countries. The outcomes of DOLS and FMOLS indicate that energy consumption and political institutions had increased the ecological footprint. Similarly, Muhammad and Long [43] found a negative and significant association between the rule of law and $\mathrm{CO}_{2}$ emissions in 65 belt and road initiative (BRI) countries. Omri and Hadj [19] and Castiglione et al. [44] observed that countries that respect laws and regulations, having private property rights, and market allocation of resources were developing faster than those economies in which these freedoms were limited. Moreover, Gholipour and Farzanegan [45] and Omri and Hadj [19], in their studies, found that good governance and the rule of law significantly reduced the amount of pollution.

GDP is also one of the important determinants of environmental quality. ZambranoMonserrate and Fernandez [46] observed that increased GDP due to the technique effect led to a quadratic association between income and $\mathrm{N}_{2} \mathrm{O}$ emissions by validating the EKC hypothesis. Moreover, Copeland and Taylor [47] and Chang [48] observed that if economic growth came through trade openness, then environmental quality deteriorated with economic growth, and eventually such scale effect of income was offset by the technological changes due to changes in preferences of the people [49].

Very few studies related to environmental quality in South Asian countries have been found in previous literature. For instance, Sun et al. [25] measured the environmental sustainability performance of South Asian countries with the help of Data Envelopment Analysis (DEA). The results revealed that Bhutan outperformed the rest of South Asian countries. Nepal was second with a stable ranking, followed by the Maldives. Pakistan had shown the worst performance for environmental sustainability. For long-term environmental sustainability, the South Asian countries should boost cross-border renewable trade. Hunjra et al. [29] analyzed the impact of institutional quality and financial development on environmental degradation in five countries of South Asia (Bangladesh, Pakistan, India, Sri Lanka, and Nepal) for the years 1985 to 2018. It was found that financial development increased $\mathrm{CO}_{2}$ emissions while institutional quality moderated the negative association between financial development and environmental quality. In another study, Mehmood and Tariq [50] found an inverted U-shaped association between globalization and $\mathrm{CO}_{2}$ emissions in South Asian countries.

Table 2 shows the summary of previous studies, which shows the relationship between natural resources, globalization, and environmental quality.

Table 2 shows the summary of previous studies, which shows the relationship between.

It is clear from the review that a lot of studies analyzed this association for various groups of countries and provide different findings, but in the case of South Asian countries, very limited studies exist (see Mehmood and Tariq [50] and Sun et al. [25]), which leaves room for comprehensive research to examine this relationship in terms of a specific group of countries, i.e., South Asia. Hence, this issue is still disputable and will directly influence the fairness and inclusiveness of environmental governance policies. 
Table 2. Summary of the Previous Empirical Literature.

\begin{tabular}{|c|c|c|c|c|}
\hline Author(s) & Sample Period/Countries & Methodology & Dependent Variable & $\begin{array}{c}\text { Findings/Relationship of } \\
\text { Independent Variables with } \\
\text { Dependent Variable }\end{array}$ \\
\hline Neumayer [34] & 1968-1988/106 countries & Ordinary least squares (OLS) & $\mathrm{CO}_{2}$ emissions per capita & $\begin{array}{l}\text { Natural resources explained the } \\
\text { cross-country differences in } \\
\mathrm{CO}_{2} \text { emissions }\end{array}$ \\
\hline Balsalobre-Lorente et al. [3] & 1985-2016/EU countries & Panel least squares (PLS) & $\mathrm{CO}_{2}$ emissions & $\begin{array}{l}\text { Natural resources }(-) \text {, electricity } \\
\text { consumption }(-)\end{array}$ \\
\hline Zafar et al. [21] & 1970-2015/United States & ARDL & Ecological footprint & $\begin{array}{c}\text { Natural resources }(-), \text { human capital } \\
(-), \text { economic growth }(-), \text { energy } \\
\text { consumption }(-)\end{array}$ \\
\hline Hassan et al. [2] & 1970-2014/Pakistan & ARDL & Ecological footprint & $\begin{array}{l}\text { Natural resources }(+), \text { GDP growth }(+) \\
\text { urbanization }(-)\end{array}$ \\
\hline Twerefou et al. [36] & $\begin{array}{l}\text { 1990-2013/Sub-Saharan African } \\
\text { countries }\end{array}$ & System-GMM & $\mathrm{CO}_{2}$ emissions per capita & $\begin{array}{c}\text { Globalization }(+), \text { GDP growth }(+), \\
\text { trade openness }(+), \text { FDI }(+) \text {, EKC exists }\end{array}$ \\
\hline Figge et al. [8] & 1990-2014/183 countries & multivariate regression model & Ecological footprint & $\begin{array}{c}\text { Overall globalization }(+) \text {, economic } \\
\text { globalization }(+) \text {, GDP per capita }(+,-)\end{array}$ \\
\hline Rudolph and Figge [7] & 1981-2009/146 countries & Extreme bounds analysis (EBA) & Ecological footprint & $\begin{array}{c}\text { Overall Globalization (+), political } \\
\text { globalization }(+), \\
\text { Social globalization }(-)\end{array}$ \\
\hline You and Lv [9] & $\begin{array}{l}\text { 1985-2013/83 developed and } \\
\text { developing countries }\end{array}$ & Spatial panel method & $\mathrm{CO}_{2}$ emissions & $\begin{array}{c}\text { Globalization }(+) \text {, GDP }(+) \text {, population } \\
(+) \text {, industrialization }(+) \text {, urbanization } \\
(+), \text { EKC hypothesis exists }\end{array}$ \\
\hline
\end{tabular}


Table 2. Cont.

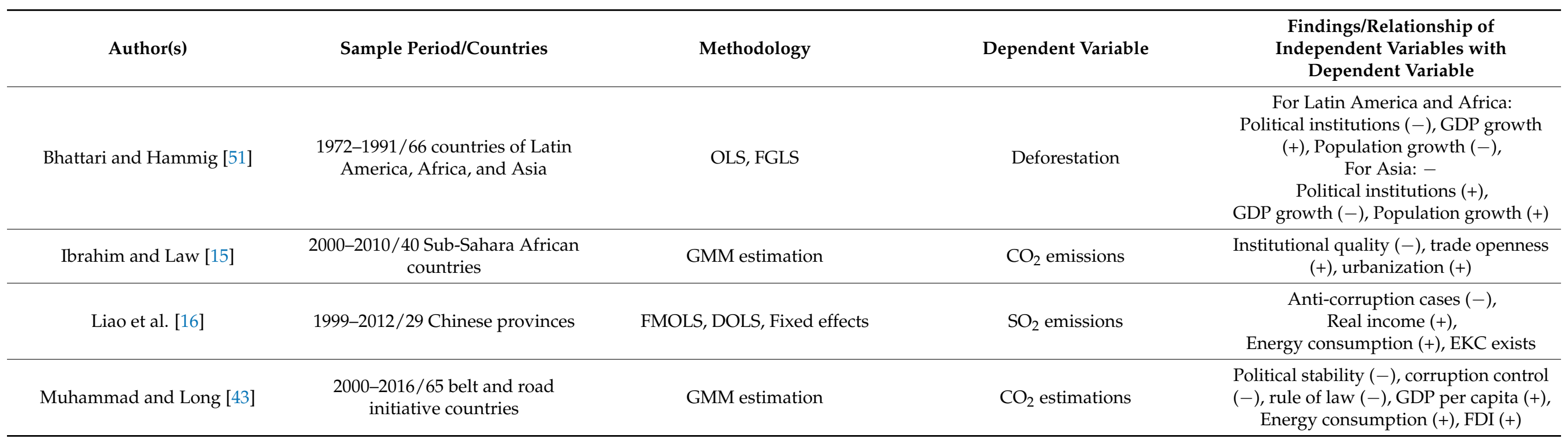




\section{Data and Methodology}

In this study, the relationship between extraction of natural resources, globalization, institutional performance, and environmental quality is observed for South Asian countries. Out of eight South Asian countries, six (India, Pakistan, Bangladesh, Sri Lanka, Nepal, and Bhutan) are selected for the analysis according to data availability for the period 1991-2018. Our four models have different dependent variables (three pollutants, i.e., $\mathrm{CO}_{2}, \mathrm{CH}_{4}$, and $\mathrm{N}_{2} \mathrm{O}$, along with a new indicator, ecological footprint). The independent variables are per capita natural resources, globalization, institutional performance, energy consumption, and GDP per capita. The reason for selecting the above-mentioned pollutants as environmental indicators is their significant share in GHG emissions. $\mathrm{CO}_{2}$ emissions are the most significant contributors to GHG emissions, followed by $\mathrm{CH}_{4}$ and $\mathrm{N}_{2} \mathrm{O} . \mathrm{CO}_{2}$ emissions are primarily produced from the consumption of energy, transportation, and industrial output [52]. $\mathrm{CH}_{4}$ is generated during the consumption of natural gas, oil and coal [53], while $\mathrm{N}_{2} \mathrm{O}$ emissions are emitted from agricultural activities [54]. The ecological footprint, on the other hand, is a modern instrument to measure the environmental quality, which reflects the ecological and biological aspects of the earth.

Different conventional panel data techniques have been utilized by previous studies like PMG (pooled mean group), GMM (generalized method of movement), CCE (common correlated effects), and fixed effect (FE) models. However, these traditional methodologies consider homogeneity and ignore the issue of heterogeneity in the data, which is common in the real world in panel data $[55,56]$. Moreover, several times, panel data models apt to suffer from the issue of cross-sectional dependence (CSD) as the result of unobserved factors and economic shocks that arise due to globalization and economic integration of countries [56]. Hence, every country has significantly suffered from economic changes in other countries [56,57]. Therefore, nowadays, researchers across the globe are more interested in CSD between cross-sectional units. To tackle such issue of CSD, a new panel data methodology, "dynamic common correlated effects (DCCE)" by Chudik and Pesaran [58], is helpful, which can tackle the issue of CSD by assuming that a common factor can represent the variables.

The DCCE approach is created on the principles of Mean group (MG) estimation proposed by Pesaran and Smith [59], pooled mean group (PMG) technique developed by Pesaran et al. [60], and CCE (common correlated effects) methodology developed by Pesaran [61]. Blackburne and Frank [62] suggested PMG estimation with xtpmg command for non-stationary and heterogeneous large data sets. PMG estimation combines both averaging and pooling of the data. However, error variances, intercepts, and slope coefficients are allowed to change across different groups of data [62], but the main issue of PMG estimation is that it does not allow CSD between the cross-sectional units [56].

Eberhardt [63] recommended CCE estimation through xtcce command. The CCE command considers the cross-sectional average of both dependent and independent variables to attain an unobserved common factor. However, the CCE approach does not take the lag value of an endogenous variable as an explanatory variable [58]. Although CCE estimation is robust to serial correlation, nonstationarity, and structural breaks, it is inadequate for dynamic panel data due to its failure to take into account the lag of dependent variable as strictly exogenous [58]. A fixed-effects (FE) technique also considers heterogeneity by pooling the time-series observations and changing intercepts across the groups, but the main problem of FE methodology is that it generates potentially misleading and inconsistent outcomes if the slope coefficients are not identical $[56,64]$.

On the other hand, through the DCCE approach of Chudik and Pesaran [58], the estimator becomes more persistent by adding cross-sectional lags in regression equations. This approach can deal with various critical issues that are not considered by other conventional methodologies: (i) this methodology takes the averages and logs of all cross-sectional units to tackle the problem of CSD. (ii) It can deal with heterogeneity through the mean group (MG) estimation properties. Moreover, it assesses dynamic common correlated effects by taking heterogeneous slopes and presuming that a common factor can represent the 
variables. (iii) DCCE methodology can also give robust outcomes if data is small in size by initiating Jackknife command. We can use the jackknife command in STATA to estimate robust variance and robust standard error. (iv) This approach works excellently when our data suffered from structural breaks [65] or in the case of unbalanced panel data [64].

The models of our study are predicated on the findings of Grossman and Krueger [10] and Zafar et al. [21], which have recognized the impact of globalization and natural resources on environmental quality. Along with globalization and natural resources, we have incorporated other important determining factors of environmental quality, i.e., institutional performance, GDP per capita, and energy consumption, to prevent omitted variables bias. Heterogeneity and CSD issues of data are excellently dealt with DCCE approach by considering heterogeneous slopes where parameters change across crosssections.

On the basis of the above-mentioned specifications, we can write the DCCE equation as below:

$$
Y_{i t}=\alpha_{i} Y_{i t-1}+\delta_{i} X_{i t}+\sum_{p=0}^{p_{T}} \gamma_{x i p} \bar{X}_{t-p}+\sum_{p=0}^{p_{T}} \gamma_{y i p} \bar{X}_{t-p}+\mu_{i t}
$$

Here, $t$ and $i$ indicate time and cross-sections, respectively. $Y_{i t}$ and $Y_{i t-1}$ represent the dependent variable and its lag, respectively. $P_{T}$ shows the lag of cross-sectional averages. The set of other independent variables is shown by $X_{i t}$. The unobserved common factors are represented by $\gamma_{x i p}$ and $\gamma_{y i p} . \mu_{i t}$ denotes the error term.

The model of Equation (1) is further extended into the following four models by using various proxies of environmental quality according to our objectives of the study.

$$
\begin{aligned}
& \mathrm{LNCO}_{2 i t}=\alpha_{i} \mathrm{LNCO}_{2 i t-1}+\delta_{i} X_{i t}+\sum_{p=0}^{p_{T}} \gamma_{x i p} \bar{X}_{t-p}+\sum_{p=0}^{p_{T}} \gamma_{y i p} \bar{X}_{t-p}+\mu_{i t}(\text { Model 1) } \\
& \mathrm{LNCH}_{4 i t}=\alpha_{i} \mathrm{LNCH}_{4 i t-1}+\delta_{i} \mathrm{X}_{i t}+\sum_{p=0}^{p_{T}} \gamma_{x i p} \bar{X}_{t-p}+\sum_{p=0}^{p_{T}} \gamma_{y i p} \bar{X}_{t-p}+\varepsilon_{i t}(\text { Model 2) } \\
& L N N_{2} O_{i t}=\alpha_{i} L N N_{2} O_{i t-1}+\delta_{i} X_{i t}+\sum_{p=0}^{p_{T}} \gamma_{x i p} \bar{X}_{t-p}+\sum_{p=0}^{p_{T}} \gamma_{y i p} \bar{X}_{t-p}+e_{i t}(\text { Model 3) } \\
& L N E C F_{i t}=\alpha_{i} L N E C F_{i t-1}+\delta_{i} X_{i t}+\sum_{p=0}^{p_{T}} \gamma_{x i p} \bar{X}_{t-p}+\sum_{p=0}^{p_{T}} \gamma_{y i p} \bar{X}_{t-p}+v_{i t}(\text { Model } 4)
\end{aligned}
$$

$\mathrm{LNCO}_{2}$ (log of per capita $\mathrm{CO}_{2}$ emissions), $\mathrm{LNCH}_{4}$ (log of Methane emissions), $\mathrm{LNN}_{2} \mathrm{O}$ ( $\log$ of $\mathrm{N}_{2} \mathrm{O}$ emissions), and LNECF (log of per capita ecological footprint) in Model 1, 2, 3 , and 4, respectively, are dependent variables that are used as proxies of environmental quality, and the lags of these dependent variables are taken as independent variables. Log of per capita natural resources, the log of globalization, the log of institutional performance, the log of GDP per capita, and the log of per capita energy consumption are other independent variables that are represented by $X_{i t}$. Moreover, $\mu_{i t}, \varepsilon_{i t}, e_{i t}$, and $v_{i t}$ are error terms of the models.

One of the main problems of previous studies is that they take a single variable as a proxy for institutional performance, such as corruption [16,66], government stability [67], law and order [43,68], and religious tensions [69]. Using a single variable as a proxy for institutional performance could result in biased or misleading outcomes [17,70]. Moreover, including all the indicators in one equation is not an easy task [71]. Therefore, we have obtained an institutional performance index (INP) made up of five institutional indicators (socioeconomic conditions, law and order, government stability, investment profile and corruption) through the method of principal component analysis (PCA). These institutional indicators reflect different issues and factors that significantly affect environmental quality [17]. We followed Hosseini and Kaneko [72], Law et al. [70], and Ali et al. [17] for constructing PCA (the STATA command pca is used for calculating the institutional perfor- 
mance index (INP)). This index duplicates all the original data of institutional indicators into one variable with minimal loss of information [73].

The jth factor index in PCA technique can be written as:

$$
\mathrm{INP}_{\mathrm{j}}=\mathrm{W}_{\mathrm{j} 1} \mathrm{X}_{1}+\mathrm{W}_{\mathrm{j} 2} \mathrm{X}_{2}+\mathrm{W}_{\mathrm{j} 3} \mathrm{X}_{3}+\mathrm{W}_{\mathrm{j} 4} \mathrm{X}_{4}+\mathrm{W}_{\mathrm{j} 5} \mathrm{X}_{5}
$$

Here, $\mathrm{INP}_{\mathrm{j}}$ represents the institutional performance index. $\mathrm{W}_{\mathrm{j}}$ denotes the respective weights of the parameters. $X_{1}, X_{2}, \ldots, X_{5}$ show the values of institutional indicators (socioeconomic condition, government stability, corruption, investment profile, and law and order).

The previous studies of Maddala and Wu [74], Levin et al. [75], and Im et al. [76] relied on 1st generation unit root tests, which have ignored the issue of CSD. Therefore, in this study, we have applied the CIPS test, which is a 2nd generation unit root test developed by Choi and Chue [77] and Pesaran [78], and which gives more authentic results in the presence of CSD. The null hypothesis of no CSD is verified against our alternative hypothesis of CSD. A bootstrap cointegration approach by Westerlund [79] is employed to estimate long-run estimates, which is preferred on traditional cointegration tests because it considers CSD, structural breaks, and heteroscedasticity [80]. The description of variables, along with data sources, is presented in Table 3.

Table 3. Description of Variables and Data Sources.

\begin{tabular}{|c|c|c|c|}
\hline Variables & Description & Unit of Measurement & Data Sources \\
\hline $\mathrm{LNCO}_{2}$ & $\log$ of per capita $\mathrm{CO}_{2}$ emissions & Kilo ton (kt) & World Bank \\
\hline $\mathrm{LNCH}_{4}$ & log of Methane emissions & kt of $\mathrm{CO}_{2}$ equivalent & World Bank \\
\hline $\mathrm{LNN}_{2} \mathrm{O}$ & log of Nitrous oxide emissions & thousand metric tons of $\mathrm{CO}_{2}$ equivalent & World Bank \\
\hline LNECF & log of per capita ecological footprint & Global hectares (gha) & Global Footprint Network \\
\hline LNTNR & $\begin{array}{l}\log \text { of the amount of total natural } \\
\text { resources per capita }\end{array}$ & $\begin{array}{l}\text { Composite index of per capita rents of } \\
\text { natural gas, oil, coal, minerals, and } \\
\text { forests(constant } 2010 \text { US\$) }\end{array}$ & World Bank \\
\hline LNENC & log of per capita energy consumption & $\mathrm{kg}$ of oil equivalent per capita & World Bank \\
\hline LNGDP & log of GDP per capita & constant 2010 US\$ & World Bank \\
\hline LNINP & $\begin{array}{l}\text { Log of institutional } \\
\text { performance index }\end{array}$ & $\begin{array}{l}\text { calculated through panel principal } \\
\text { component analysis (PCA) }\end{array}$ & $\begin{array}{c}\text { International Country Risk } \\
\text { Guide (ICRG) }\end{array}$ \\
\hline LNKOF & Log of globalization & KOF globalization index & KOF Swiss Economic Institute \\
\hline
\end{tabular}

\section{Results and Discussion}

Table 4 represents the descriptive statistics of all the variables (in log form). Pair-wise correlation of variables is also given, which shows the level of association among variables. All our independent variables are significantly correlated with dependent variables.

Due to globalization and economic conditions, the panel data these days suffer from CSD. As shown in Table 5, we have employed various tests to verify the presence of CSD, i.e., Pesaran-CD (the STATA command 'xtcd' is used for CD test) and Pesaranscaled LM tests presented by Pesaran [81], and bias-adjusted scaled LM test proposed by Baltagi et al. [82]. The outcomes of these tests are useful in deciding the estimation technique and also help to make a decision that whether the 1st generation unit root tests of Levin et al. [75] and Im et al. [76] are appropriate, which consider no CSD, or whether the 2nd generation unit root tests by Chang [83] and Pesaran [78] are more suitable, which assume the CSD.

The above CSD tests are checked against the null hypothesis of no CSD, and according to the outcomes of the tests, we reject the null hypothesis and confirm that CSD exists among the cross-sectional units. Due to the presence of CSD, the 2nd generation unit root tests are more suitable than the 1st generation unit root tests.

Table 6 shows the outcomes of the 2 nd generation unit root test (CIPS-Test) proposed by Pesaran [78], which considers the CSD in data (the STATA command 'xtcips' is used for 
CIPS test). All the variables are stationary at the level, and their first difference, and none of the variables are stationary at the second difference.

Table 4. Descriptive Statistics of Variables and Pair-wise Correlation.

\begin{tabular}{|c|c|c|c|c|c|c|c|c|c|}
\hline & $\mathrm{LNCO}_{2}$ & $\mathrm{LNCH}_{4}$ & $\mathrm{LNN}_{2} \mathrm{O}$ & LNECF & LNTNR & LNKOF & LNINP & LNENC & GDP \\
\hline Mean & -0.29 & 3.95 & 3.33 & -0.04 & 1.08 & 1.72 & 0.54 & 2.53 & 3.01 \\
\hline Median & -0.21 & 4.32 & 3.62 & -0.07 & 0.96 & 1.73 & 0.51 & 2.58 & 2.97 \\
\hline Minimum & -1.55 & 1.13 & 0.32 & -0.11 & 0.25 & 1.44 & -3.76 & 2.07 & 2.56 \\
\hline Maximum & 0.48 & 5.83 & 5.43 & 0.08 & 2.12 & 1.90 & 3.94 & 2.80 & 3.59 \\
\hline Skewness & -0.65 & -0.67 & -0.55 & 0.48 & 0.37 & -0.43 & -0.10 & -1.16 & 0.41 \\
\hline Std.Dev. & 0.42 & 1.46 & 1.46 & 0.07 & 0.48 & 0.09 & 1.63 & 0.17 & 0.25 \\
\hline Kurtosis & 3.18 & 2.22 & 2.27 & 1.69 & 2.09 & 2.79 & 2.23 & 3.32 & 2.40 \\
\hline Observations & 168 & 168 & 168 & 168 & 168 & 168 & 168 & 168 & 168 \\
\hline $\mathrm{LNCO}_{2}$ & 1 & $0.28^{*}$ & $0.15^{*}$ & $0.15^{*}$ & $0.62 *$ & $-0.10 *$ & $-0.62 *$ & $0.69 *$ & 0.74 * \\
\hline $\mathrm{LNCH}_{4}$ & & 1 & $0.38 *$ & 0.24 * & 0.70 * & $-0.46^{*}$ & -0.70 * & $0.67 *$ & $0.65 *$ \\
\hline $\mathrm{LNN}_{2} \mathrm{O}$ & & & 1 & 0.34 * & 0.78 * & $-0.39 *$ & 0.78 * & $0.52 *$ & 0.68 * \\
\hline LNECF & & & & 1 & $-0.60 *$ & -0.33 * & $-0.60 *$ & 0.80 * & 0.84 * \\
\hline LNTNR & & & & & 1 & $0.47^{*}$ & $0.42 *$ & 0.57 * & 0.20 \\
\hline LNKOF & & & & & & 1 & $0.45^{*}$ & 0.45 * & 0.15 \\
\hline LNINP & & & & & & & 1 & 0.32 * & 0.34 * \\
\hline LNENC & & & & & & & & 1 & 0.52 * \\
\hline LNGDP & & & & & & & & & 1 \\
\hline
\end{tabular}

Note: * shows 1 percent level of significance.

Table 5. Results of cross-sectional dependence tests.

\begin{tabular}{ccccccc}
\hline \multirow{2}{*}{ Variables } & \multicolumn{2}{c}{ Pesaran-CD } & \multicolumn{2}{c}{ Pesaran-Scaled LM } & \multicolumn{2}{c}{ Bias-Adjusted Scaled LM } \\
\cline { 2 - 6 } & Statistic & Probability & Statistic & Probability & Statistic & Probability \\
\hline $\mathrm{LNCO}_{2}$ & 31.83 & $0.00 *$ & $129.39 *$ & $0.00 *$ & 128.40 & $0.00 *$ \\
$\mathrm{LNCH}_{4}$ & 80.72 & $0.00 *$ & $221.21 *$ & $0.00 *$ & 220.14 & $0.00 *$ \\
$\mathrm{LNN}_{2} \mathrm{O}$ & 27.85 & $0.00^{*}$ & $130.30 *$ & $0.00 *$ & 129.23 & $0.00 *$ \\
$\mathrm{LNECF}$ & 130.64 & $0.00 *$ & 381.03 & $0.00 *$ & 380.13 & $0.00 *$ \\
$\mathrm{LNTNR}$ & 54.14 & $0.00 *$ & 144.47 & $0.00 *$ & 143.61 & $0.00 *$ \\
$\mathrm{LNKOF}$ & 87.99 & $0.00 *$ & 272.57 & $0.00 *$ & 271.67 & $0.00 *$ \\
$\mathrm{LNINP}$ & 45.53 & $0.01 *$ & 108.25 & $0.00 *$ & 107.39 & $0.00 *$ \\
LNENC & 67.86 & $0.00^{*}$ & 196.54 & $0.00 *$ & 195.91 & $0.00 *$ \\
LNGDP & 129.32 & $0.01 *$ & 400.37 & $0.01 *$ & 399.51 & $0.02 * *$ \\
\hline
\end{tabular}

Note: ${ }^{*}$ and ${ }^{* *}$ show 1 percent and 5 percent level of significance, respectively.

Table 6. Results of CIPS-Test.

\begin{tabular}{ccc}
\hline & Level & 1st Difference \\
\hline $\mathrm{LNCO}_{2}$ & -1.89 & $-6.14^{*}$ \\
$\mathrm{LNCH}_{4}$ & $-2.58^{* *}$ & $-5.10^{*}$ \\
$\mathrm{LNN}_{2} \mathrm{O}$ & $-2.30^{*}$ & $-4.09^{*}$ \\
$\mathrm{LNECF}$ & $-2.96^{*}$ & $-5.52^{*}$ \\
$\mathrm{LNTNR}$ & $-2.30^{* *}$ & $-4.09 *$ \\
$\mathrm{LNKOF}$ & $-2.58^{*}$ & $-5.10^{*}$ \\
LNINP & $-2.76^{*}$ & $-5.22^{*}$ \\
LNENC & $-2.36^{* *}$ & $-5.06^{*}$ \\
LNGDP & $-2.50^{*}$ & $-4.56^{*}$ \\
\hline
\end{tabular}

Note: * and ${ }^{* *}$ refer to the levels of significance at 1 percent and 5 percent, respectively.

Slope Homogeneity Test

The result of the slope homogeneity test (the STATA command ' $x$ thst' is used for slope homogeneity test) of Pesaran et al. [84] is presented in Table 7. This test rejects the null hypothesis that slope coefficients of the models are homogenous (no heterogeneity) and accepts the alternative hypothesis that slope coefficients are not homogenous (heterogeneity). 
Table 7. Outcomes of Slope Homogeneity Test.

\begin{tabular}{ccc}
\hline & $\bar{\Delta}$ & $\bar{\Delta}_{\text {adj }}$ \\
\hline Model 1 & $6.63^{*}$ & $7.12^{*}$ \\
Model 2 & $7.17^{*}$ & $8.13^{*}$ \\
Model 3 & $5.40^{*}$ & $5.97^{*}$ \\
Model 4 & $5.38^{*}$ & $6.19^{*}$ \\
\hline
\end{tabular}

Note: * refers to the level of significance at 1 percent.

In Table $7,(\bar{\Delta})$ and $\bar{\Delta}_{\text {adj }}$ show the values of t-statistics of slope homogeneity test and its bias-adjusted version, respectively. The results of this test give us sufficient indication for the presence of country-specific heterogeneity in all our models.

It is decided by slope homogeneity test whether the coefficients of cross-sections are homogeneous or heterogeneous in the long-run. In modern times, due to CSD, each country is influenced by economic changes of other economies and may have similar dynamics [84]. Assuming slope homogeneity in the case of heterogeneous panel data leads to misleading or biased outcomes [17]. As a consequence, the slope homogeneity test is useful to define the existence of cross-sectional heterogeneity while analyzing the empirical findings.

The long-run relationship among the variables is analyzed through Westerlund [79] panel cointegration test as shown in Table 8. The STATA command 'xtwest' developed by Persyn and Westerlund [84] is used for this test. Westerlund [79] test considers many important problems like heteroskedasticity, CSD, structural breaks, and serial correlation. These issues are ignored in traditional cointegration tests like Pedroni [85] cointegration test. Therefore, the outcomes of Westerlund [79] are more reliable.

Table 8. Westerlund panel cointegration test results.

\begin{tabular}{ccccccccc}
\hline $\mathrm{H}_{\mathbf{0}}$ : No Cointegration & \multicolumn{2}{c}{ Model 1 } & \multicolumn{2}{c}{ Model 2 } & \multicolumn{2}{c}{ Model 3 } & \multicolumn{2}{c}{ Model 4 } \\
\hline Statistic & Value & $\begin{array}{c}\text { Robust } \\
p \text {-Value }\end{array}$ & Value & $\begin{array}{c}\text { Robust } \\
p \text {-Value }\end{array}$ & Value & $\begin{array}{c}\text { Robust } \\
p \text {-Value }\end{array}$ & $\begin{array}{c}\text { Value } \\
\begin{array}{c}\text { Robust } \\
p \text {-Value }\end{array}\end{array}$ \\
\hline Group- $\mathrm{T}$ & $-3.04^{* *}$ & 0.01 & $-3.65^{*}$ & 0.00 & $-3.92^{*}$ & 0.00 & $-4.19^{*}$ & 0.00 \\
\hline Group- $\alpha$ & $-3.05^{*}$ & 0.00 & $-3.29 *$ & 0.00 & -2.48 & 0.00 & $-4.37^{*}$ & 0.00 \\
\hline Panel-T & $-7.40^{*}$ & 0.00 & $-5.80 * *$ & 0.02 & $-8.04^{*}$ & 0.00 & $-3.68^{*}$ & 0.00 \\
\hline Panel- $\alpha$ & $-3.18^{*}$ & 0.00 & -2.64 & 0.00 & $-3.04^{*}$ & 0.00 & $-3.96^{* *}$ & 0.02 \\
\hline
\end{tabular}

Note: ${ }^{*}$ and ${ }^{* *}$ refer to the level of significance at 1 percent and 5 percent, respectively.

The test statistics values of Westerlund [79] cointegration test (Group-T, Group- $\alpha$, Panel-T, and Panel- $\alpha$ ) are significant according to their robust $p$-values. We have checked the null hypothesis of no cointegration against the alternative hypothesis of cointegration. According to the outcomes of test statistics, we reject the null hypothesis and confirm the existence of a long-run relationship among the variables. The outcomes of this test are aligning with the findings of Meo et al. [56] and Ali et al. [17], who also used the Westerlund cointegration test [79] to observe long-run association among the variables.

Table 9 indicates the DCCE estimation in the short-run and long-run. The STATA command xtdcce2 developed by Ditzen [64] is used for DCCE estimation. We have used xtdcce2 command developed by Ditzen [64] to implement the DCCE estimation of Chudik and Pesaran [58]. Independent variables in all our models have shown significant relationships with the lagged values of dependent variables $\left(\mathrm{L}^{\mathrm{LNNCO}}, \mathrm{L} . \mathrm{LNCH}_{4}, \mathrm{~L} . \mathrm{LNN}_{2} \mathrm{O}\right.$, and L.LNECF). The short-run elasticities of globalization, natural resources, and institutional performance for GHG emissions $\left(\mathrm{CO}_{2}, \mathrm{CH}_{4}\right.$, and $\left.\mathrm{N}_{2} \mathrm{O}\right)$ are more than long-run elasticities. It is found that globalization and energy consumption have more substantial effects on environmental indicators than other variables. 
Table 9. Results of Dynamic Common Correlated Effects (DCCE) estimation.

\begin{tabular}{|c|c|c|c|c|c|}
\hline & & $\begin{array}{c}\text { Model } 1 \\
\left(\mathrm{LNCO}_{2}\right)\end{array}$ & $\begin{array}{c}\text { Model } 2 \\
\left(\mathrm{LNCH}_{4}\right)\end{array}$ & $\begin{array}{c}\text { Model } 3 \\
\left(\mathrm{LNN}_{2} \mathrm{O}\right)\end{array}$ & $\begin{array}{l}\text { Model } 4 \\
\text { (LNECF) }\end{array}$ \\
\hline & Regressors & Coefficient & Coefficient & Coefficient & Coefficient \\
\hline \multirow{5}{*}{$\begin{array}{l}\text { Short-run } \\
\text { Estimates }\end{array}$} & D.LNTNR & $\begin{array}{l}0.37 \text { * } \\
(0.00)\end{array}$ & $\begin{array}{l}0.30 * \\
(0.00)\end{array}$ & $\begin{array}{l}0.35 \text { * } \\
(0.00)\end{array}$ & $\begin{array}{c}-0.30 * \\
(0.01)\end{array}$ \\
\hline & D.LNKOF & $\begin{array}{c}-1.90 * \\
(0.01)\end{array}$ & $\begin{array}{c}-2.2 \\
(0.15)\end{array}$ & $\begin{array}{c}-1.10 * \\
(0.00)\end{array}$ & $\begin{array}{l}1.17^{*} \\
(0.00)\end{array}$ \\
\hline & D.LNINP & $\begin{array}{c}-0.10 * * \\
(0.02)\end{array}$ & $\begin{array}{c}-0.18^{* *} \\
(0.03)\end{array}$ & $\begin{array}{c}0.08 \\
(0.11)\end{array}$ & $\begin{array}{c}-0.05 * \\
(0.00)\end{array}$ \\
\hline & D.LNENC & $\begin{array}{c}0.58^{* *} \\
(0.02)\end{array}$ & $\begin{array}{l}0.60 * \\
(0.00)\end{array}$ & $\begin{array}{l}0.52 \text { ** } \\
(0.02)\end{array}$ & $\begin{array}{c}0.45 \\
(0.12)\end{array}$ \\
\hline & D.LNGDP & $\begin{array}{c}0.32 * * \\
(0.03) \\
\end{array}$ & $\begin{array}{l}0.30 \text { * } \\
(0.01)\end{array}$ & $\begin{array}{c}0.23^{* *} \\
(0.03)\end{array}$ & $\begin{array}{l}0.28 \text { * } \\
(0.01)\end{array}$ \\
\hline \multirow{9}{*}{$\begin{array}{l}\text { Long-run } \\
\text { Estimates }\end{array}$} & L.LNCO ${ }_{2}$ & $\begin{array}{c}-0.60 \text { ** } \\
(0.03)\end{array}$ & 一 & 一 & 一 \\
\hline & L. $\mathrm{LNCH}_{4}$ & - & $\begin{array}{c}-0.78^{*} \\
(0.01)\end{array}$ & - & - \\
\hline & L.LNN ${ }_{2} \mathrm{O}$ & - & - & $\begin{array}{c}-0.70 \text { * } \\
(0.00)\end{array}$ & 一 \\
\hline & L.LNECF & 一 & - & - & $\begin{array}{c}-0.65 \text { * } \\
(0.01)\end{array}$ \\
\hline & LNTNR & $\begin{array}{l}0.32 * \\
(0.01)\end{array}$ & $\begin{array}{l}0.28 * \\
(0.00)\end{array}$ & $\begin{array}{l}0.25 * \\
(0.00)\end{array}$ & $\begin{array}{c}-0.32 * \\
(0.00)\end{array}$ \\
\hline & LNKOF & $\begin{array}{c}-1.50 * * \\
(0.02)\end{array}$ & $\begin{array}{l}-2.10 \\
(0.20)\end{array}$ & $\begin{array}{c}-0.98 * \\
(0.00)\end{array}$ & $\begin{array}{l}1.20 \text { * } \\
(0.01)\end{array}$ \\
\hline & LNINP & $\begin{array}{c}-0.09 * \\
(0.00)\end{array}$ & $\begin{array}{c}-0.15^{* * *} \\
(0.06)\end{array}$ & $\begin{array}{l}0.06^{*} \\
(0.00)\end{array}$ & $\begin{array}{c}-0.07^{*} \\
(0.01)\end{array}$ \\
\hline & LNENC & $\begin{array}{l}0.50 \text { ** } \\
(0.02)\end{array}$ & $\begin{array}{l}0.65^{*} \\
(0.01)\end{array}$ & $\begin{array}{l}0.55^{* *} \\
(0.02)\end{array}$ & $\begin{array}{l}0.48^{*} \\
(0.00)\end{array}$ \\
\hline & LNGDP & $\begin{array}{l}0.30 \text { ** } \\
(0.02)\end{array}$ & $\begin{array}{l}0.28 \text { ** } \\
(0.02)\end{array}$ & $\begin{array}{l}0.20 \text { ** } \\
(0.04)\end{array}$ & $\begin{array}{c}-0.32^{* * *} \\
(0.07)\end{array}$ \\
\hline
\end{tabular}

Note: ${ }^{*}, * *$ and ${ }^{* * *}$ refer to the levels of significance at 1 percent, 5 percent and 10 percent, respectively. ( ) shows the probability value.

Natural resources show a positive and significant association with all GHG emissions in South Asian countries. These outcomes are aligning with the findings of Grossman and Krueger [10] and Cole and Elliot [11], who found that the scale effect leads to the expansion of economic activities due to the use of natural resources and energy consumption, which results in the deterioration of the environmental quality in the economy. However, natural resources indicate a negative association with the ecological footprint, implying that they have a positive contribution to environmental quality. This relationship is backed up by the studies of Zafar et al. [21] and Danish et al. [86]. The transformation from old technologies (that cause the exploitation of natural resources) to advanced technologies that integrate reprocessing, recycling, value-addition, and artificial resources that replace natural resources will lead to improved environmental quality (Danish et al., 2020). Natural resource abundance decreases the dependency on the import of fossil fuel since it is sufficient to fulfill the energy requirements, and eventually, it may decrease ecological footprint $[21,86]$. Moreover, energy consumption demonstrates a positive and significant relationship with all GHG emissions and ecological footprint in both the short-run and long-run, which indicates that increased consumption of energy deteriorates environmental quality in South Asian countries.

The short-run and long-run estimates show that globalization indicates a significant and negative relationship with $\mathrm{CO}_{2}$ and $\mathrm{N}_{2} \mathrm{O}$ emissions, which shows that environmental quality improves with the increased globalization in South Asian countries. The results align with the studies of Zaidi [14] and Sharif et al. [37]. One of the possible reasons for this negative relationship between globalization and GHG emissions can be explained 
by the theory of Antweiler et al. [87], which argues that environmental quality improves when technique effect dominates on composition and scale effects. Moreover, globalization has an insignificant relationship with $\mathrm{CH}_{4}$ emissions in both the short-run and long-run. However, we find that globalization has a positive association with the ecological footprint, which shows that environmental quality deteriorates with the increase in globalization. The finding is in line with Rudolph and Figge [7]. The possible reason for the positive association between globalization and ecological footprint in South Asian countries is that ecological footprint is comprised of many components (i.e., biocapacity, cropland, grazing land, fishing land, carbon footprint, and forest product) which are seriously impacted by human and industrial activities due to globalization [7].

The institutional performance shows a significant and negative linkage with $\mathrm{CO}_{2}$, $\mathrm{CH}_{4}$, and ecological footprint in both the short-run and long-run. It shows that better performance of institutional determinants, i.e., socioeconomic conditions, the stability of government, law and order, and control of corruption, will increase the environmental quality in South Asian countries. The findings are aligned with Bhattari and Hammig [51], Zeinalzadeh et al. [41] and Liao et al. [16]. Furthermore, the association between institutional performance and $\mathrm{N}_{2} \mathrm{O}$ emissions is positive but insignificant in the short-run, which becomes significant in the long-run. The possible reason for this long-run relationship between institutional performance and $\mathrm{N}_{2} \mathrm{O}$ emissions is that $\mathrm{N}_{2} \mathrm{O}$ emissions are primarily produced from agricultural activities (use of nitrogen-fertilizers, waterlogging and croptillage, etc.) [54] and South Asian countries are under-developed, having a large share of the agriculture sector that makes a significant contribution in economic activities of these countries [88]. In the development process, an increase in institutional performance (stability of government, control on corruption, a better situation of law and order, and improved socioeconomic conditions) leads to enhance agricultural activities, which causes an increase in $\mathrm{N}_{2} \mathrm{O}$ emissions.

The short-run and long-run estimates demonstrate a positive and significant relationship of GDP per capita with all GHG emissions except with ecological footprint, where it shows a negative and significant association. The positive linkage of GDP per capita with environmental indicators in South Asian countries is consistent with the studies of Ahmed et al. [89] and Lin [90]. This relationship is valid in the early phase of development under the scale effect in which environmental quality deteriorates due to the increase of economic activities (transportation, deforestation, and industrial output) and energy consumption. The negative relationship between per capita GDP and ecological footprint in South Asian countries is consistent with the results of Zafar et al. [21]. There are two possible reasons for this negative association: (i) when under technique effect, the income level of the people increases, and they demand a clean environment to achieve better living standards. (ii) Under the composition effect, the production of dirty products is superseded by cleaner technologies or the services sector, which leads to improved environmental quality.

\section{Concluding Remarks and Recommendations}

This study has evaluated the impact of extraction of natural resources and globalization on the environmental quantity in South Asian countries for the period 1991-2018 by taking GHG emissions and ecological footprint as environmental indicators. Various CSD tests confirm the existence of CSD in cross-sectional units. The slope homogeneity test confirms the presence of heterogeneity in data. To deal with the weaknesses of traditional methods, a newly developed DCCE approach is applied, which considers the issue of CSD. Long-run results of DCCE estimation for South Asian countries indicate a positive and significant relationship of natural resources with all GHG emissions and a negative association with the ecological footprint. Globalization shows a negative relationship with $\mathrm{CO}_{2}$ and $\mathrm{N}_{2} \mathrm{O}$ emissions and a positive association with the ecological footprint. Institutional performance is negatively correlated with $\mathrm{CO}_{2}, \mathrm{CH}_{4}$, and ecological footprint while positively associated with $\mathrm{N}_{2} \mathrm{O}$ emissions. 
South Asian countries should work with indigenous communities and stakeholders for a greater understanding of the impacts of natural resources and globalization on biodiversity. They should make advanced policies that can help their communities to become more resilient, secure, and restore natural ecosystems such as wetlands, helping landscapes, ecosystems and species adapt to changes in climate. South Asian countries should move towards capital-intensive production rather than labor-intensive technology, as capital-intensive technique leads to more efficient technology which involves cleaner processes, cleaner production, and green investment. If the cost of being clean is low for new investment but high for retrofitting, it induces cleaner processes, leading to less GHG emissions. Green technology is a suitable option for sustainable development goals (SDGs) like green energy, low-cost production, better health, openness, infrastructure, responsible production and consumption, and environmental quality. Knowing about the factors which have positive or negative effects on natural resources will lead to a better understanding of the potential of the business, production, and sustainable environment. Environmental policies should also emphasize raising public awareness about the importance of less resource-intensive lifestyle since the over-extraction of resources increases GHG emissions and ecological footprint. In addition, the efficient management and utilization of natural resources would contribute to the goals of the green economy and improved environmental quality.

The negative and significant impact of globalization on $\mathrm{CO}_{2}$ emissions and $\mathrm{N}_{2} \mathrm{O}$ emissions in South Asian countries support the Pollution Halo Hypothesis, which states that due to globalization, foreign firms bring cleaner and advanced technologies to host economies, which will reduce GHG emissions. Hence, governments of South Asian countries can play significant roles to get the benefits of globalization by improving economic conditions, making arrangements to bring foreign investment and thus protecting the environment. However, globalization has a positive relationship with the ecological footprint, which demonstrates that the environment degrades with an increase in globalization when we consider ecological footprint as an environmental indicator. Ecological footprint consists of many factors, i.e., biocapacity, carbon footprint, grazing land, cropland, forest products, and fishing grounds, which represent the ecological and biological capacity of the countries, which is severely affected by human and industrial activities due to globalization. Hence, South Asian countries should make arrangements to preserve their biodiversity and ecosystem so that the adverse effects of globalization on ecological footprint can be minimized. Policymakers should treat globalization as an economic tool for designing sustainable and comprehensive policy frameworks to improve environmental quality. $\mathrm{N}_{2} \mathrm{O}$ emissions are primarily generated from agricultural activities. So, the consensus between globalization and $\mathrm{N}_{2} \mathrm{O}$ emissions is, therefore, compulsory to make agriculture policies and plans that guarantee equilibrium between globalization and the environmental impact of agricultural activities.

The institutional performance has significantly reduced $\mathrm{CO}_{2}$ emissions, $\mathrm{CH}_{4}$ emissions, and ecological footprint, which shows that better performance of institutional determinants, i.e., socioeconomic conditions, the stability of government, law and order, and control of corruption, increases the environmental quality in South Asian countries. The policies to strengthening the institutions in South Asian countries should be continued by improving socioeconomic conditions, better investment profile, the stability of government, control of corruption, and enforcement of law and order. It is observed from our findings that institutional performance enhances the level of $\mathrm{N}_{2} \mathrm{O}$ emissions in South Asia. As previously mentioned, $\mathrm{N}_{2} \mathrm{O}$ emissions are primarily produced from agricultural activities (use of nitrogen-fertilizers, waterlogging and crop-tillage, etc.) and South Asian countries have a large share of the agriculture sector, which makes a significant contribution to the economic activities of these countries. In the development process, an improvement in institutional performance in the form of stability of government, control on corruption, a better situation of law and order, and improved socioeconomic conditions lead to enhancement of agricultural activities, which causes an increase in $\mathrm{N}_{2} \mathrm{O}$ emissions. So, the 
government institutions in South Asian countries should make rules and regulations to mitigate the emissions from the agriculture sector $\left(\mathrm{N}_{2} \mathrm{O}\right.$ emissions) by managing the use of nitrogen-fertilizers, waterlogging and crop-tillage, etc. These countries should make effective rules and regulations for the better integration of the issue of $\mathrm{N}_{2} \mathrm{O}$ emissions. $\mathrm{N}_{2} \mathrm{O}$ emissions can be reduced by making and implementing the rules about lessened use of nitrogen fertilizers, minimum tillage for cropping, prevention of waterlogging, and use of nitrification inhibitors. This will help steer transformative actions for the economic, social, and environmental sustainability in food and agriculture for many generations to come.

South Asian countries should make more integrated transport policies that include clean energy carriers such as biodiesels, hydrogen, renewable energy sources, and electricity. GHG emissions from the industrial sector can be reduced in many ways, including energy efficiency, fuel switching, combined heat and power, recycling of materials, and the use of renewable energy. Moreover, GHG emissions can also be reduced by slowing down the deforestation process, sustainable management of forests, and conservation of natural forests, biological diversity, and forest carbon stocks. Energy sector reforms are compulsory for the improvement of environmental quality in South Asia. South Asian countries should encourage effective and efficient energy use, upgrade old-fashioned technology towards modern techniques of production, and develop renewable energy sources to reduce the share of energy consumption in environmental degradation. Old climate-aggravating energy sources (hydropower is not green) should be replaced by eco-friendly energy sources like solar, small wind, oceanic, geothermal, and other projects.

The outcomes of this research are not only beneficial for South-Asian countries, which are considered developing countries but also useful for developed economies. The developed economies may be more suffered from environmental consequences due to their increased industrial activities, globalization, and extraction of natural resources. In the end, we want to give some limitations for our tested models, which will provide direction for future research in this field. First, we have skipped some GHG emissions in our models, like sulfur hexafluoride $\left(\mathrm{SF}_{6}\right)$, sulfur dioxide $\left(\mathrm{SO}_{2}\right)$, hydrofluorocarbons (HFCs), and perfluorocarbons (PFCs), due to the unavailability of data. Moreover, we have taken the amount of per capita ecological footprint rather than using its sub-items (carbon footprint, biocapacity, cropland, fishing grounds, forest products, and grazing lands). In future studies, we can use the above-mentioned environmental proxies to see how the findings vary across these indicators. Second, we have selected six countries out of eight South Asian economies by dropping two countries (Afghanistan and Maldives) due to the non-availability of data. The future research will clearly elaborate the models upon the availability of data about missing countries. Third, in future research, the impact of globalization can be further decomposed into economic globalization, social globalization, and political globalization for the clear elaboration of its implications on environmental quality.

Author Contributions: This article is the result of the joint work by all authors, who equally contributed to conceive, design, and carry out the research. All authors collaborated in analyzing the data, preparing the results, visualization, and writing the paper. All authors have read and agreed to the published version of the manuscript.

Funding: The study is funded by "The Natural Science Basic Research Plan in Shaanxi Province of China" and project number is 2018JM7005.

Institutional Review Board Statement: Not applicable.

Informed Consent Statement: Not applicable.

Data Availability Statement: The data that support the findings are available from the corresponding author upon reasonable request.

Conflicts of Interest: The authors declare no conflict of interest and agree to submit the manuscript. 


\section{References}

1. Gao, J.; Tian, M. Analysis of over-consumption of natural resources and the ecological trade deficit in China based on ecological footprints. Ecol. Indic. 2016, 61, 899-904. [CrossRef]

2. Hassan, S.T.; Xia, E.; Khan, N.H.; Shah, S.M.A. Economic growth, natural resources, and ecological footprints: Evidence from Pakistan. Environ. Sci. Pollut. Res. Int. 2019, 26, 2929-2938. [CrossRef]

3. Balsalobre-Lorente, D.; Shahbaz, M.; Roubaud, D.; Farhani, S. How economic growth, renewable electricity and natural resources contribute to $\mathrm{CO}_{2}$ emissions? Energy Policy 2018, 113, 356-367. [CrossRef]

4. Bai, L.; Jiang, L.; Yang, D.-Y.; Liu, Y.-B. Quantifying the spatial heterogeneity influences of natural and socioeconomic factors and their interactions on air pollution using the geographical detector method: A case study of the Yangtze River Economic Belt, China. J. Clean. Prod. 2019, 232, 692-704. [CrossRef]

5. Global Footprint Network. Obtenido de Global Footprint Network 2018. Available online: http://www.footprintnetwork.org (accessed on 5 April 2021).

6. Ahmadov, A.K.; van der Borg, C. Do natural resources impede renewable energy production in the EU? A mixed-methods analysis. Energy Policy 2019, 126, 361-369. [CrossRef]

7. Rudolph, A.; Figge, L. Determinants of ecological footprints: What is the role of globalization? Ecol. Indic. 2017, 81, 348-361. [CrossRef]

8. Figge, L.; Oebels, K.; Offermans, A. The effects of globalization on Ecological Footprints: An empirical analysis. Environ. Dev. Sustain. 2016, 19, 863-876. [CrossRef]

9. You, W.; Lv, Z. Spillover effects of economic globalization on $\mathrm{CO}_{2}$ emissions: A spatial panel approach. Energy Econ. 2018, 73, 248-257. [CrossRef]

10. Grossman, G.M.; Krueger, A.B. Environmental Impacts of a North American Free Trade Agreement; National Bureau of Economic Research: Cambridge, MA, USA, 1991.

11. Cole, M.A.; Elliott, R.J. Determining the trade-environment composition effect: The role of capital, labor and environmental regulations. J. Environ. Econ. Manag. 2003, 46, 363-383. [CrossRef]

12. Zhang, N.; Yu, K.; Chen, Z. How does urbanization affect carbon dioxide emissions? A cross-country panel data analysis. Energy Policy 2017, 107, 678-687. [CrossRef]

13. Shahbaz, M.; Shahzad, S.J.H.; Mahalik, M.K.; Sadorsky, P. How strong is the causal relationship between globalization and energy consumption in developed economies? A country-specific time-series and panel analysis. Appl. Econ. 2018, 50, 1479-1494. [CrossRef]

14. Zaidi, S.A.H.; Zafar, M.W.; Shahbaz, M.; Hou, F. Dynamic linkages between globalization, financial development and carbon emissions: Evidence from Asia Pacific Economic Cooperation countries. J. Clean. Prod. 2019, 228, 533-543. [CrossRef]

15. Ibrahim, M.H.; Law, S.H. Institutional quality and $\mathrm{CO}_{2}$ emission-Trade relations: Evidence from Sub-Saharan Africa. S. Afr. J. Econ. 2016, 84, 323-340. [CrossRef]

16. Liao, X.; Dogan, E.; Baek, J. Does corruption matter for the environment? Panel evidence from China. Econ. Open Access Open Assess. EJ. 2017. [CrossRef]

17. Ali, S.; Yusop, Z.; Kaliappan, S.R.; Chin, L. Dynamic common correlated effects of trade openness, FDI, and institutional performance on environmental quality: Evidence from OIC countries. Environ. Sci. Pollut. Res. Int. 2020, 27, 11671-11682. [CrossRef]

18. Dasgupta, S.; De Cian, E.; Verdolini, E. The political economy of energy innovation. Political Econ. Clean Energy Transit. 2016, 123. [CrossRef]

19. Omri, A.; Hadj, T.B. Foreign investment and air pollution: Do good governance and technological innovation matter? Environ. Res. 2020, 185, 109469. [CrossRef]

20. Frankel, J.A.; Rose, A.K. Is trade good or bad for the environment? Sorting out the causality. Rev. Econ. Stat. 2005, 87, 85-91. [CrossRef]

21. Zafar, M.W.; Zaidi, S.A.H.; Khan, N.R.; Mirza, F.M.; Hou, F.; Kirmani, S.A.A. The impact of natural resources, human capital, and foreign direct investment on the ecological footprint: The case of the United States. Resour. Policy 2019, 63, 101428. [CrossRef]

22. Destek, M.A.; Ulucak, R.; Dogan, E. Analyzing the environmental Kuznets curve for the EU countries: The role of ecological footprint. Environ. Sci. Pollut. Res. Int. 2018, 25, 29387-29396. [CrossRef]

23. Dogan, E.; Taspinar, N.; Gokmenoglu, K.K. Determinants of ecological footprint in MINT countries. Energy Environ. 2019, 30, 1065-1086. [CrossRef]

24. Uddin, G.A.; Salahuddin, M.; Alam, K.; Gow, J. Ecological footprint and real income: Panel data evidence from the 27 highest emitting countries. Ecol. Indic. 2017, 77, 166-175. [CrossRef]

25. Sun, H. Measuring environmental sustainability performance of South Asia. J. Clean. Prod. 2020, 251, 119519. [CrossRef]

26. Rahman, M.M.; Velayutham, E. Renewable and non-renewable energy consumption-economic growth nexus: New evidence from South Asia. Renew. Energy 2020, 147, 399-408. [CrossRef]

27. Mohsin, M.; Zhang, J.; Saidur, R.; Sun, H.; Sait, S.M. Economic assessment and ranking of wind power potential using fuzzyTOPSIS approach. Environ. Sci. Pollut. Res. Int. 2019, 26, 22494-22511. [CrossRef]

28. Abbas, S.Z.; Kousar, A.; Razzaq, S.; Saeed, A.; Alam, M.; Mahmood, A. Energy management in South Asia. Energy Strat. Rev. 2018, 21, 25-34. [CrossRef] 
29. Hunjra, A.I.; Tayachi, T.; Chani, M.I.; Verhoeven, P.; Mehmood, A. The moderating effect of institutional quality on the financial development and environmental quality nexus. Sustainability 2020, 12, 3805. [CrossRef]

30. Mrabet, Z.; Alsamara, M. Testing the Kuznets Curve hypothesis for Qatar: A comparison between carbon dioxide and ecological footprint. Renew. Sustain. Energy Rev. 2017, 70, 1366-1375. [CrossRef]

31. Young, O.R. The politics of international regime formation: Managing natural resources and the environment. Int. Organ. 1989, 43, 349-375. [CrossRef]

32. Sachs, J.; Warner, A. Natural Resource Abundance and Economic Growth; National Bureau of Economic Research: Cambridge, MA, USA, 1995.

33. Auty, R.M. How natural resources affect economic development. Dev. Policy Rev. 2000, 18, 347-364. [CrossRef]

34. Neumayer, E. Can natural factors explain any cross-country differences in carbon dioxide emissions? Energy Policy 2002, 30, 7-12. [CrossRef]

35. Dreher, A.; Gaston, N.; Martens, W.J.M. Measuring Globalisation—Gauging its Consequences; Springer: New York, NY, USA, 2008.

36. Twerefou, D.K.; Danso-Mensah, K.; Bokpin, G.A. The environmental effects of economic growth and globalization in Sub-Saharan Africa: A panel general method of moments approach. Res. Int. Bus. Financ. 2017, 42, 939-949. [CrossRef]

37. Sharif, A.; Afshan, S.; Qureshi, M.A. Idolization and ramification between globalization and ecological footprints: Evidence from quantile-on-quantile approach. Environ. Sci. Pollut. Res. Int. 2019, 26, 11191-11211. [CrossRef] [PubMed]

38. Deacon, R. Dictatorship, Democracy, and the Provision of Public Goods; University of California: Santa Barbara, CA, USA, 2003.

39. Torras, M.; Boyce, J.K. Income, inequality, and pollution: A reassessment of the environmental Kuznets Curve. Ecol. Econ. 1998, 25, 147-160. [CrossRef]

40. Cole, M.A. Corruption, income and the environment: An empirical analysis. Ecol. Econ. 2007, 62, 637-647. [CrossRef]

41. Zeinalzadeh, R.; Nekooei, M.H.; Sadeghi, Z. The effects of democracy on environment quality index in selected OIC countries. Iran. J. Econ. Stud. 2015, 4, 113-133.

42. Charfeddine, L.; Mrabet, Z. The impact of economic development and social-political factors on ecological footprint: A panel data analysis for 15 MENA countries. Renew. Sustain. Energy Rev. 2017, 76, 138-154. [CrossRef]

43. Muhammad, S.; Long, X. Rule of law and $\mathrm{CO}_{2}$ emissions: A comparative analysis across 65 belt and road initiative(BRI) countries. J. Clean. Prod. 2021, 279, 123539. [CrossRef]

44. Castiglione, C.; Infante, D.; Smirnova, J. Rule of law and the environmental Kuznets curve: Evidence for carbon emissions. Int. J. Sustain. Econ. 2012, 4, 254. [CrossRef]

45. Gholipour, H.F.; Farzanegan, M.R. Institutions and the effectiveness of expenditures on environmental protection: Evidence from Middle Eastern countries. Const. Polit. Econ. 2017, 29, 20-39. [CrossRef]

46. Zambrano-Monserrate, M.A.; Fernandez, M.A. An environmental kuznets curve for $\mathrm{N}_{2} \mathrm{O}$ emissions in Germany: An ARDL approach. Nat. Resour. Forum 2017, 41, 119-127. [CrossRef]

47. Copeland, B.R.; Taylor, M.S. Free trade and global warming: A trade theory view of the Kyoto protocol. J. Environ. Econ. Manag. 2005, 49, 205-234. [CrossRef]

48. Chang, N. The empirical relationship between openness and environmental pollution in China. J. Environ. Plan. Manag. 2012, 55, 783-796. [CrossRef]

49. Song, M.-L.; Cao, S.-P.; Wang, S.-H. The impact of knowledge trade on sustainable development and environment-biased technical progress. Technol. Forecast. Soc. Chang. 2019, 144, 512-523. [CrossRef]

50. Mehmood, U.; Tariq, S. Globalization and CO2 emissions nexus: Evidence from the EKC hypothesis in South Asian countries. Environ. Sci. Pollut. Res. Int. 2020, 27, 37044-37056. [CrossRef] [PubMed]

51. Bhattarai, M.; Hammig, M. Institutions and the environmental kuznets curve for deforestation: A cross country analysis for Latin America, Africa and Asia. World Dev. 2001, 29, 995-1010. [CrossRef]

52. Li, R.; Jiang, H.; Sotnyk, I.; Kubatko, O.; A., I.A.Y. The $\mathrm{CO}_{2}$ emissions drivers of post-communist economies in Eastern Europe and Central Asia. Atmosphere 2020, 11, 1019. [CrossRef]

53. Yusuf, A.M.; Abubakar, A.B.; Mamman, S.O. Relationship between greenhouse gas emission, energy consumption, and economic growth: Evidence from some selected oil-producing African countries. Environ. Sci. Pollut. Res. Int. 2020, 27, 15815-15823. [CrossRef]

54. Aneja, V.P.; Schlesinger, W.H.; Li, Q.; Nahas, A.; Battye, W.H. Characterization of atmospheric nitrous oxide emissions from global agricultural soils. SN Appl. Sci. 2019, 1, 1662. [CrossRef]

55. Dogan, E.; Seker, F.; Bulbul, S. Investigating the impacts of energy consumption, real GDP, tourism and trade on $\mathrm{CO}_{2}$ emissions by accounting for cross-sectional dependence: A panel study of OECD countries. Curr. Issues Tour. 2015, 20, 1701-1719. [CrossRef]

56. Meo, M.S.; Sabir, S.A.; Arain, H.; Nazar, R. Water resources and tourism development in South Asia: An application of dynamic common correlated effect (DCCE) model. Environ. Sci. Pollut. Res. Int. 2020, 27, 19678-19687. [CrossRef]

57. Latif, Z.; Mengke, Y.; Danish; Latif, S.; Ximei, L.; Pathan, Z.H.; Salam, S.; Jianqiu, Z. The dynamics of ICT, foreign direct investment, globalization and economic growth: Panel estimation robust to hetero-geneity and cross-sectional dependence. Telemat. Inform. 2018, 35, 318-328. [CrossRef]

58. Chudik, A.; Pesaran, M.H. Common correlated effects estimation of heterogeneous dynamic panel data models with weakly exogenous regressors. J. Econom. 2015, 188, 393-420. [CrossRef] 
59. Pesaran, M.; Smith, R. Estimating long-run relationships from dynamic heterogeneous panels. J. Econom. 1995, 68, 79-113. [CrossRef]

60. Pesaran, M.H.; Shin, Y.; Smith, R.J. Testing for the 'Existence of a Long-Run Relationship'; Faculty of Economics-University of Cambridge: Cambridge, UK, 1996.

61. Pesaran, M.H. Estimation and inference in large heterogeneous panels with a multifactor error structure. Econometrica 2006, 74, 967-1012. [CrossRef]

62. Blackburne, E.F., III; Frank, M.W. Estimation of nonstationary heterogeneous panels. Stata J. 2007, 7, 197-208. [CrossRef]

63. Eberhardt, M. Estimating Panel Time-Series Models with Heterogeneous Slopes. Stata J. 2012, 12, 61-71. [CrossRef]

64. Ditzen, J. Estimating Long Run Rffects in Models with Cross-Sectional Dependence Using xtdcce2; Centre for Energy Economics Research and Policy (CEERP): Edinburgh, UK, 2019.

65. Kapetanios, G.; Pesaran, M.H.; Yamagata, T. Panels with non-stationary multifactor error structures. J. Econom. 2011, 160, 326-348. [CrossRef]

66. Saha, S.; Yap, G. Corruption and tourism: An empirical investigation in a non-linear framework. Int. J. Tour. Res. 2015, 17, 272-281. [CrossRef]

67. Habibi, F. The determinants of inbound tourism to Malaysia: A panel data analysis. Curr. Issues Tour. 2016, 20, 909-930. [CrossRef]

68. Bilgin, M.H.; Gozgor, G.; Demir, E. The determinants of Turkey's exports to Islamic countries: The impact of political risks. J. Int. Trade Econ. Dev. 2018, 27, 486-503. [CrossRef]

69. Shtudiner, Z.; Klein, G.; Kantor, J. How religiosity affects the attitudes of communities towards tourism in a sacred city: The case of Jerusalem. Tour. Manag. 2018, 69, 167-179. [CrossRef]

70. Law, S.H.; Tan, H.B.; Azman-Saini, W.N.W. Financial development and income inequality at different levels of institutional quality. Emerg. Mark. Finance Trade 2014, 50, 21-33. [CrossRef]

71. Sabir, S.; Rafique, A.; Abbas, K. Institutions and FDI: Evidence from developed and developing countries. Financ. Innov. 2019, 5, 8. [CrossRef]

72. Hosseini, H.M.; Kaneko, S. Causality between pillars of sustainable development: Global stylized facts or regional phenomena? Ecol. Indic. 2012, 14, 197-201. [CrossRef]

73. Khan, M.A.; Abdulahi, M.E.; Liaqat, I.; Shah, S.S.H. Institutional quality and financial development: The United States perspective. J. Multinatl. Financ. Manag. 2019, 49, 67-80. [CrossRef]

74. Maddala, G.S.; Wu, S. A comparative study of unit root tests with panel data and a new simple test. Oxf. Bull. Econ. Stat. 1999, 61, 631-652. [CrossRef]

75. Levin, A.; Lin, C.-F.; Chu, C.-S.J. Unit root tests in panel data: Asymptotic and finite-sample properties. J. Econom. 2002, 108, 1-24. [CrossRef]

76. Im, K.S.; Pesaran, M.; Shin, Y. Testing for unit roots in heterogeneous panels. J. Econom. 2003, 115, 53-74. [CrossRef]

77. Choi, I.; Chue, T.K. Subsampling hypothesis tests for nonstationary panels with applications to exchange rates and stock prices. J. Appl. Econom. 2007, 22, 233-264. [CrossRef]

78. Pesaran, M.H. A simple panel unit root test in the presence of cross-section dependence. J. Appl. Econom. 2007, 22, 265-312. [CrossRef]

79. Westerlund, J. Testing for Error Correction in Panel Data. Oxf. Bull. Econ. Stat. 2007, 69, 709-748. [CrossRef]

80. Persyn, D.; Westerlund, J. Error-correction-based cointegration tests for panel data. Stata J. 2008, 8, 232-241. [CrossRef]

81. Pesaran, M.H. General diagnostic tests for cross-sectional dependence in panels. Empir. Econ. 2004, 60, 1-38. [CrossRef]

82. Baltagi, B.H.; Feng, Q.; Kao, C. A Lagrange Multiplier test for cross-sectional dependence in a fixed effects panel data model. J. Econom. 2012, 170, 164-177. [CrossRef]

83. Chang, Y. Bootstrap unit root tests in panels with cross-sectional dependency. J. Econom. 2004, 120, 263-293. [CrossRef]

84. Pesaran, M.H.; Ullah, A.; Yamagata, T. A bias-adjusted LM test of error cross-section independence. Econom. J. 2008, 11, 105-127. [CrossRef]

85. Pedroni, P. Critical values for cointegration tests in heterogeneous panels with multiple regressors. Oxf. Bull. Econ. Stat. 1999, 61, 653-670. [CrossRef]

86. Danish; Ulucak, R.; Khan, S.U.-D. Determinants of the ecological footprint: Role of renewable energy, natural resources, and urbanization. Sustain. Cities Soc. 2020, 54, 101996. [CrossRef]

87. Antweiler, W.; Copeland, B.R.; Taylor, M.S. Is free trade good for the environment? Am. Econ. Rev. 2001, 91, 877-908. [CrossRef]

88. Liu, J.; Wang, M.; Yang, L.; Rahman, S.; Sriboonchitta, S. Agricultural productivity growth and its determinants in south and southeast asian countries. Sustainability 2020, 12, 4981. [CrossRef]

89. Ahmed, K.; Shahbaz, M.; Kyophilavong, P. Revisiting the emissions-energy-trade nexus: Evidence from the newly industrializing countries. Environ. Sci. Pollut. Res. 2016, 23, 7676-7691. [CrossRef] [PubMed]

90. Lin, F. Trade openness and air pollution: City-level empirical evidence from China. China Econ. Rev. 2017, 45, 78-88. [CrossRef] 